\title{
HOW INSTITUTIONS AND BUSINESS STRATEGIES AFFECT WAGES: A CROSS-NATIONAL STUDY OF CALL CENTERS
}

\author{
ROSEMARY BATT and HIROATSU NOHARA*
}

\begin{abstract}
This paper, drawing on a 2003-2006 establishment-level survey of 1,819 call centers in 15 countries, examines effects of industrial relations institutions and employer strategies on wage variation across coordinated, liberal, and emerging market economies. The authors find several contradictory patterns, which confirm theoretical predictions for some countries and contradict them for others, suggesting diverse institutional reactions to the emergence of a new economic activity. Consistent with prior research, Denmark, France, and Sweden exhibit patterns of low wage dispersion and no union wage premium, and the United States, Canada, and emerging market economies exhibit quite high levels of dispersion. Contrary to prior research, Austria and Germany resemble the United States in their levels of wage dispersion, while the United Kingdom resembles the coordinated market group. Finally, employer strategies of outsourcing and market segmentation explain within-country wage variation in most countries, suggesting considerable flexibility in wage setting at the establishment level.
\end{abstract}

$\mathbf{T}$ he literature on comparative political economy has categorized economies according to the level of coordination of their national institutions. The most familiar framework distinguishes between coordinated and liberal market economies (Hall and Soskice 2000). It builds, in part, on industrial relations (IR) research, which distinguishes between more centralized and coordinated collective bargaining systems, characteristic of continental Europe and Scandinavia, and more decentralized ones, such as those in the United States and United Kingdom. These differences in industrial re-

* Rosemary Batt is Alice H. Cook Associate Professor of Women and Work, School of Industrial and Labor Relations, Cornell University, and Hiroatsu Nohara is Senior Research Fellow, Laboratory of Labour Economics and Industrial Sociology (LEST-CNRS), Aix-Marseille University, Aix-en-Provence, France.

A data appendix with additional results, and copies of the computer programs used to generate the results presented in the paper, are available from the first author at rb41@cornell.edu. lations systems have shaped patterns of wage determination, with more centralized systems producing relatively low wage dispersion and low union wage differentials compared to more decentralized systems.

Pressures of globalization and product market deregulation, however, have eroded centralized bargaining structures in many countries, allowing employers greater leeway to alter business and compensation strategies. This raises the question of whether current wage determination patterns are consistent with past empirical findings. Some argue that countries with centralized IR systems are converging toward a decentralized model, which would suggest that wage dispersion and union wage premia in these countries more closely resemble the patterns in liberal market economies than they did in the past. Others argue that nationally specific and divergent patterns continue to be salient. A third position is that processes of convergence and divergence have occurred simultaneously, resulting in greater convergence in employment and wage practices across countries as 
well as greater divergence within countries than was characteristic of the past (Katz and Darbishire 2000).

We explore this debate by drawing on evidence from call center operations. This context is appropriate because call centers employ a growing proportion of the work force in most countries and are emblematic of new economic activities that rely on advanced information technologies (IT). As such, they are mobile operations that have challenged collective bargaining institutions or escaped them by operating outside traditional industry boundaries. In addition, we incorporate into this study evidence from emerging market economies, which typically have not been included in studies of comparative political economy and industrial relations. Including these countries is important because the call center sector, like other IT sectors, includes international competition between advanced and emerging markets.

We focus on two questions. First, does the degree of centralization in industrial relations systems shape the level of wage dispersion in new service activities such as call centers? Second, what is the relative importance of these institutions and employer strategies in explaining wage variation within countries? These two sets of factors are linked because the degree of centralization influences the extent of flexibility in wage setting at establishment levels. As centralized systems break down, employers may have new opportunities for wage setting at the organizational level (Brown, Marginson, and Walsh 2003). Thus, employer strategies are prime candidates for explaining patterns of wage dispersion within countries, over-and-above the effects of unions. Our wage analyses also take into account variation in the human capital requirements of these jobs. We draw on data from 15 countries in the global call center project (Holman, Batt, and Holtgrewe 2007), which used an identical establishment-level survey of one occupational group for each country in the study.

\section{Prior Literature}

We begin by briefly summarizing the past literature on how differences in national industrial relations systems affect the level of wage dispersion within countries and the extent to which countries in this study have experienced decentralization in these institutions in recent years. We then discuss the relationship between employer strategies and wages and how differences across industrial relations systems are likely to moderate that relationship.

The literature on industrial relations and wage determination generally has shown that unions raise the wages of workers they represent and lower overall wage dispersion within countries. However, the magnitude of these effects, and the effect of unions on non-union workers, depend on the specific characteristics of industrial relations systems. Of particular importance is the level of centralization in bargaining (whether it occurs at the firm, industry, or higher level) and coordination among employers, among trade unions, and between employers and unions (Calmfors and Driffil 2002; Blau and Kahn 1999; OECD 2004).

Three factors, in particular, shape the level of centralization: union density, the level at which collective bargaining occurs, and the use of "extension clauses" that extend the negotiated wage to all employers in a sector or in the economy-regardless of whether they participate in negotiations or have union members as employees. Centralized systems that score high on these factors are more inclusive because they extend bargaining coverage to larger proportions of the work force. A high statutory minimum wage buttresses these effects.

In more decentralized systems, wage bargaining occurs at the firm level or lower, with considerable wage variation across industries, across firms, and across establishments in the same firm. Unions seek to compress wage dispersion by raising the wages of lower-skilled workers, but their ability to influence the wages of non-union workers depends importantly on union density and union power. High union density creates a union "threat effect," providing incentives for non-union employers to match union wage levels and thus reducing overall dispersion and the union/non-union wage gap. 
In more centralized systems, union density is typically high, bargaining occurs at the industry (sectoral) level or higher, and coverage is extended to a large percentage of the work force, through either mandatory or voluntary compliance mechanisms. These systems raise wages at the lower end of the distribution while limiting growth at the top, thereby compressing wage dispersion; and there is no wage premium associated with union coverage, because unions have an interest in moderating wage demands to support high employment.

This literature has developed four main hypotheses. Compared to centralized systems, decentralized ones are predicted to have higher overall wage dispersion, a larger union/non-union wage gap, and higher dispersion within both the union and the nonunion sectors. In addition, the magnitude of dispersion between and within union and non-union sectors is expected to be shaped by the level of union density (OECD 1997; Blau and Kahn 1999; Blanchflower and Bryson 2002).

In principle, these predictions should hold for new business functions or operations that emerge as the economy and technology change; but outcomes depend on the specific features of the new economic activity, as well as the capacity of IR systems to incorporate new enterprises. In the case of call centers, most began and continue to operate as new business functions within established firms-referred to as "in-house" centers-so that they are covered by existing collective bargaining agreements. These agreements typically exist at the firm or establishment level in decentralized systems and at the firm/industry level in centralized systems, preserving the hypothesized differences between the two types of systems. Thus, bargaining coverage of new economy employees should reflect the collective bargaining system in the sector in which the firm is located, although union density may be lower if unions do not actively organize new members there. In general, we expect to find higher collective bargaining coverage and lower wage dispersion in centralized systems than in decentralized ones.

\section{Current Variation in Industrial Relations Systems}

Most countries, however, have experienced some level of decentralization in collective bargaining institutions in recent years (Katz and Darbishire 2000), raising the question of whether countries previously classified as centralized now more closely resemble liberal market economies. To assess the current extent of centralization in industrial relations institutions, we use five indicators-union density, collective bargaining coverage, collective bargaining level, the use of mandatory extension clauses, and the level of the statutory minimum wage. Table 1 provides data on these indicators, on the OECD measures of centralization and coordination (OECD 1997, 2004), and on our hypothesized predictions regarding wage dispersion and the union wage effect in each country. As a point of departure, we categorize our 15 countries into three groups based on the prior literature (Hall and Soskice 2000)-liberal market economies (Canada, Ireland, Israel, the United Kingdom, and the United States); coordinated economies (Austria, Denmark, France, Germany, and Sweden); and emerging market economies (Brazil, India, Poland, South Africa, and South Korea) - and below we assess the extent of decentralization in their industrial relations institutions.

Overall, the data show that liberal market economies as a group continue to have more decentralized bargaining institutions than do coordinated economies. In the former group, IR institutions are generally decentralized, with relatively low union density and bargaining coverage, union negotiations at the firm or establishment level, and no procedures for extending agreements to other firms or establishments. Most score a low "1" on the OECD centralization and coordination indices. By contrast, the coordinated economies have considerably higher union density and bargaining coverage; most have collective bargaining at the sector level with supplementary firm agreements and score 3-4 on the OECD indices. Therefore, overall we expect differences in wage dispersion and the union wage premium between coordinated and liberal market economies in this 


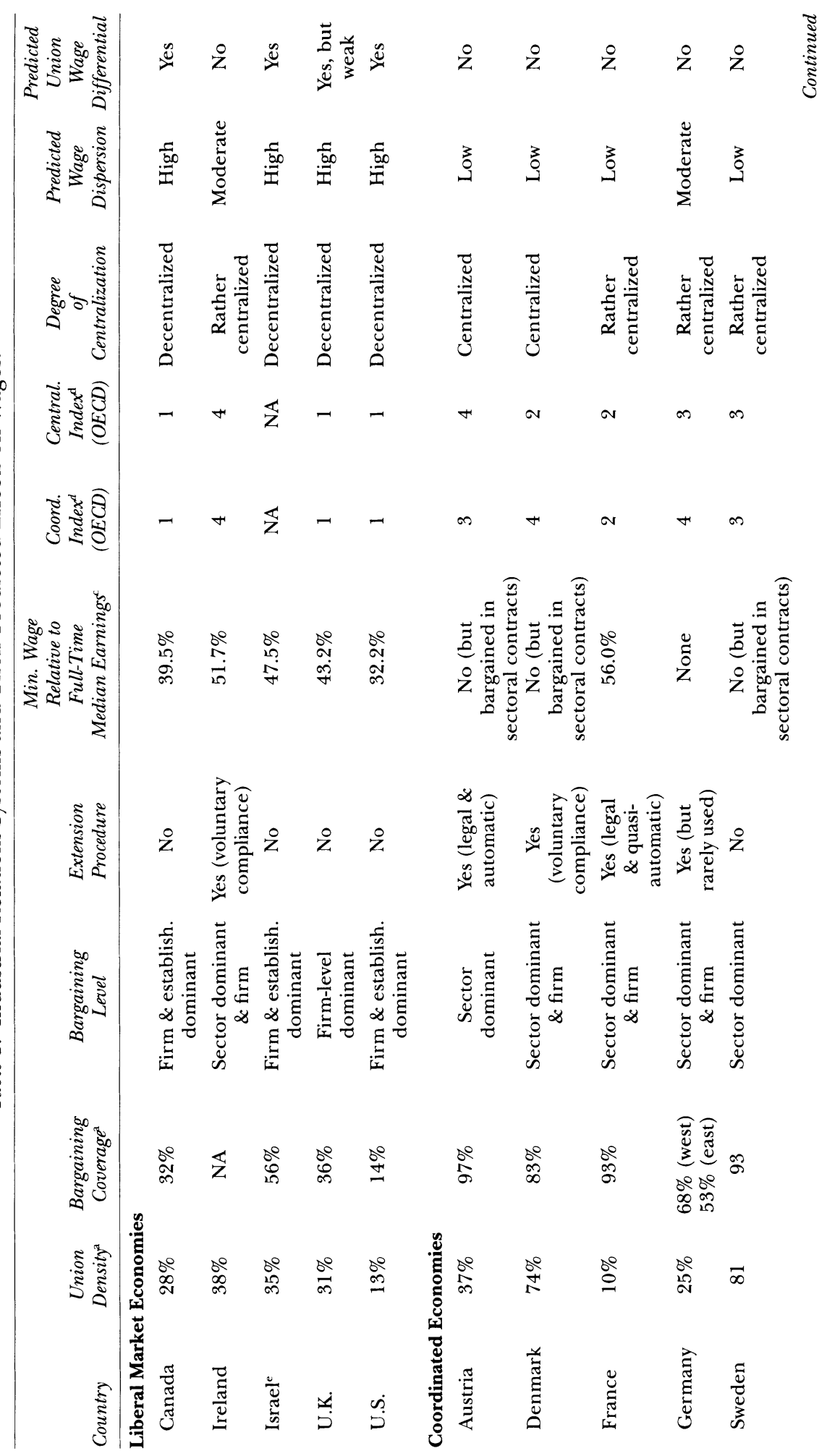




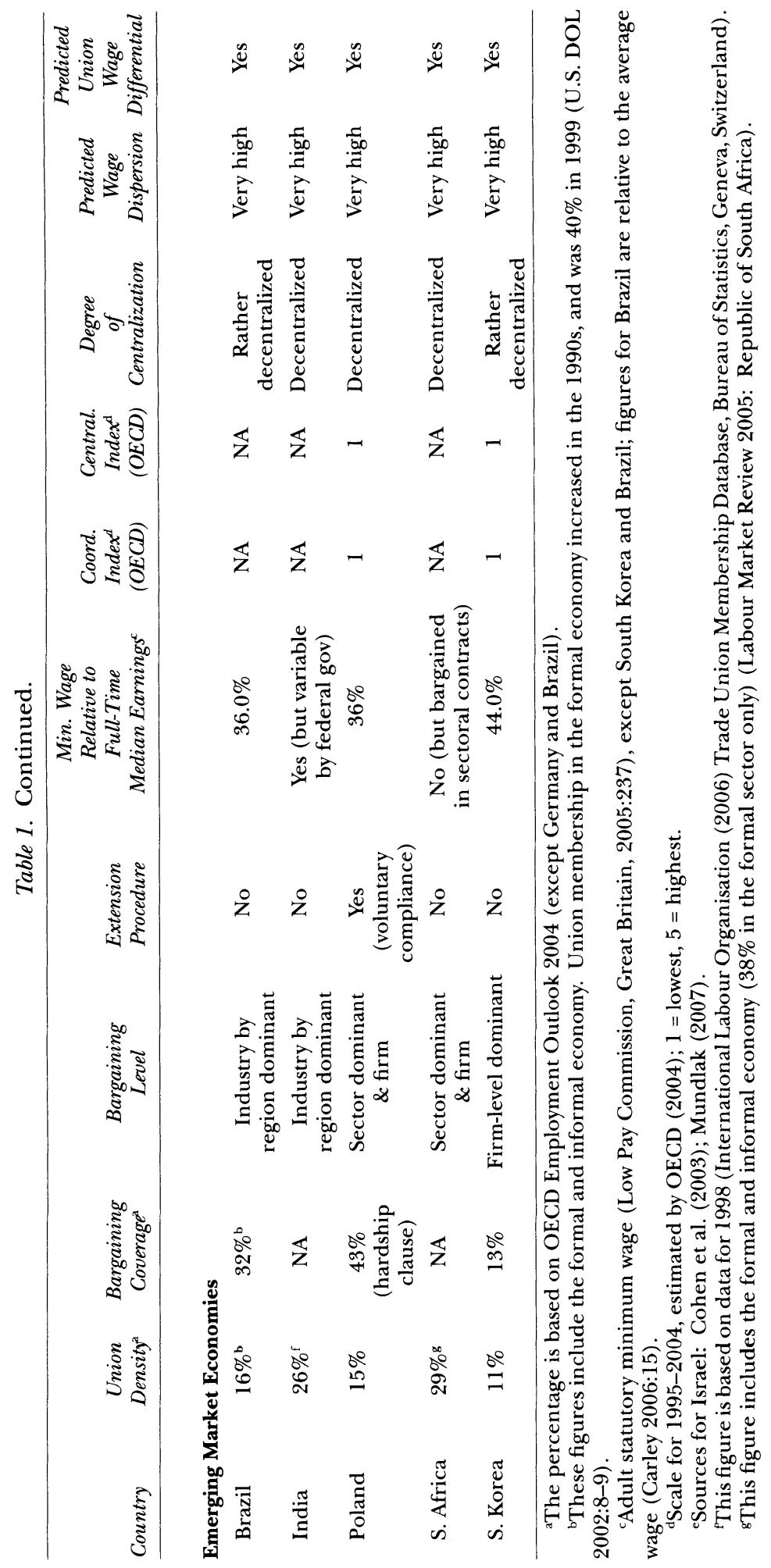


sector to follow the patterns found by prior research. The emerging market countries tend to have decentralized IR systems and should more closely follow the patterns of liberal market economies.

Among the countries in each group, however, there are some important institutional differences that should be reflected in wage patterns. Among liberal economies, the United States stands out as having the most decentralized system. Each of the other four countries has over twice the level of union density and bargaining coverage as the United States. Historically, Canada (Card and Freeman 1993) and the United Kingdom have had lower wage inequality than the United States, although the Thatcher reforms led to some increased wage inequality after 1980 (Card, Lemieux, and Riddle 2003). In addition, the union wage premium in the United Kingdom has declined sharply as union power has fallen (Blanchflower and Bryson 2002), while the statutory minimum wage system set up in 1999 has raised the wage floor. Israel, by contrast, had a strong history of corporatist industrial relations and labor law based on practices in continental Europe, and historically had low levels of wage dispersion. Since the 1970s, however, the country has relaxed labor laws and decentralized collective bargaining-leading to large declines in bargaining coverage and a growing dominance of individualized employment contracts (Mundlak 2007). Union membership fell from over $80 \%$ in 1980 to $35 \%$ in 2004 (Mundlak 2007:43). As a result, Israel's IR system is now characterized as quite decentralized. Ireland, by contrast, has some characteristics of a coordinated IR system, with a combination of firm and sector bargaining in some industries and some use of voluntary extension clauses; but we classify it with liberal market economies because of its highly deregulated economy. These differences among countries in this group suggest that wage dispersion and union differentials will be highest in the United States and lowest in Ireland, but in all cases higher than in coordinated market economies.

Among the coordinated economies, differences in national IR institutions and the approach to the minimum wage (Marginson et al. 2003; Schulten etal. 2006) should lead to different levels of wage dispersion. Denmark and Sweden have retained quite centralized systems, with high union density, a mix of sectoral and firm-level bargaining, and high bargaining coverage. While they have experienced some decentralization of bargaining, this has not led to fragmentation, because strong membership levels and an active shop steward system allow unions to negotiate effectively at the firm level. Thus, they retain a high level of coordinated activity by large, well-organized trade unions and employers' confederations (Westergaard-Nielsen 2008). France is often classified as having a lower level of centralization than other coordinated economies because of its low union density (which is comparable to that of the United States); but this is offset by the predominance of sectoral-level bargaining, mandatory extension of sectoral agreements, and a high relative minimum wage that affects $15 \%$ of all employees (Sellier 1990; Parsons 1995; Low Wage Commission 2005).

Austria also should have low wage dispersion and no union wage differentials, although some research has shown that Austrian unions have traditionally accepted a certain level of wage inequality in order to achieve other general goals, such as economic growth and employment security (Holst 2008). However, it has high union density, broad bargaining coverage, and mandatory extension clauses due in part to obligatory membership of Austrian employers in the Chamber of Commerce, which negotiates collective agreements.

In contrast to the other countries in this group, Germany's union density and bargaining coverage have fallen markedly in recent years, due in part to East German unification as well as employer decisions to break from bargaining agreements that historically were based on normative compliance. Reduced union power and low union density in many sectors have allowed firms to break from prior agreements, outsource work, or establish "hardship clauses" that allow them to cut wages when faced with economic difficulties (Bosch and Weinkopf 2008).

In sum, we expect wage dispersion in coordinated economies to be lower than in 
liberal market economies, but also expect differences between Germany and the other four coordinated economies.

The indicators in Table 1 suggest that patterns in emerging market countries are closer to those in liberal market than in coordinated market countries. All of the emerging market countries have relatively low levels of union density and collective bargaining coverage (Blanchflower 2006). Most of them share a legacy of state-controlled industrial relations that limited independent union formation until democratization movements in the 1980s; and despite very different histories and bargaining structures, their industrial relations systems are generally decentralized.

For example, Brazil's corporatist system features strong state involvement in collective bargaining as well as legislation governing employment protection, benefits, minimum wages, and wage indexation (Gonzago 2003). However, union leverage in companies is weak, with bargaining decentralized to local or regional industry and occupational units. Union dependence on government funding paradoxically creates perverse incentives to form local unions, thereby fragmenting workers' organizations; and while labor gained important rights in the 1980s, half of union contracts have not kept pace with inflation (U.S. DOL 2002:18). Poland has experienced substantial decline in union density (now at $14 \%$ ); and while unions have tried to build a sectoral and regional bargaining system with extension provisions through a tripartite commission, "hardship clauses" allow firms to set lower wage standards (Behrens and Traxler 2003). South Korea tripled the number of enterprise unions after 1987, but almost entirely among core workers in large firms (Lee and Lee 2003). The 1997 financial crisis led to widespread layoffs, elimination of lifetime employment security, a dramatic rise in contingent employment, and a $50 \%$ drop in union density (Kim and Kim 2003). Attempts to create labor peace via tripartite coordinated bargaining had only limited success, and bargaining remains at the enterprise level (Lee and Lee 2003).

Finally, in both India and South Africa, the importance of the informal sector contributes to a fragmented labor market and a limited scope for labor unions, although the legal system of industrial relations was established in India in the 1940s, and in South Africa after apartheid (Donnelly and Dunn 2006). In both countries, unions have had strength in core sectors (textiles in India and mining in South Africa), but have failed to build capacity in new sectors, such as IT or call centers, which are dominated by foreign multinationals.

In sum, despite large historic differences among these countries, the emerging market economies in this study share low union density, decentralized bargaining structures, a weak overall union movement punctuated by pockets of strength and militancy, economic crises in the 1990s that undermined union strength, and problems of unemployment and a large informal economy that create highly segmented labor markets. These characteristics suggest that the industrial relations systems in these countries are not well positioned to organize workers and influence wage policies in new sector activities such as call centers; and we expect high levels of wage dispersion. However, beyond this general prediction, the institutional literature does not provide theoretical guidance on differences among the countries in this group; we explore this issue in the empirical analysis.

\section{Employer Strategies and Industrial Relations Institutions}

Differences in industrial relations institutions also should affect employer organizational strategies and how these influence wage levels. In liberal market economies, employers face few institutional constraints-even in unionized firms, because business strategies are not mandatory subjects of bargaining. Thus, employers' ability to reorganize work and price labor according to its human capital or value added content is constrained by little other than market pressures. In coordinated market countries, by contrast, institutional incentives and constraints may shape employers' approach to doing business. Research on German manufacturing, for example, has shown that union power coupled with a strong education and training system induced a "diversified quality production" strategy 
for competing in global markets (Streeck 1991). In the context of the current study, two important employer strategies affect the structure of jobs and pay: operations strategies of outsourcing and marketing strategies of customer segmentation. Each relies on the ability to separate customer interactions into discrete tasks that may be organized into different skill hierarchies or organizational units.

\section{Outsourcing Strategies}

The outsourcing decisions of firms are likely to reflect their strategic choices. In theory, firms are likely to outsource less valueadded tasks while retaining in-house their "core competencies" that are more central to their competitiveness-such as work functions involved in providing unique products or services for more value-added customers. Thus, the skill requirements of in-house call center jobs are likely to be higher than those assigned to subcontractors-although differences may be a matter of degree, because the overall variation in skill requirements within this class of service jobs is not large. This suggests that, in general, subcontractors will offer somewhat lower wages than in-house operations.

Differences in the institutional environment, however, may shape the magnitude of differences between in-house and outsourced operations and between the wage rates they offer. In decentralized industrial relations systems, low union density and coverage coupled with low levels of employment protection against dismissals create flexible labor market conditions. Employers are free to experiment with how they use subcontractors: they may shift some moderately complex tasks to outsourced operations or create competitive contests between in-house centers and subcontractors in an effort to push down overall costs. Thus, labor market flexibility puts downward pressure on wages in this environment and may lead to a convergence in the levels of wages between in-house centers and subcontractors.

In more centralized IR systems, employers face a different constellation of incentives and constraints that may play out in differ- ent ways among the countries in this study. On the one hand, in centralized systems with high union density, such as Denmark and Sweden, subcontractors who operate outside traditional industry boundaries may feel pressure to conform to prevailing wage rates. In France, the high minimum wage is likely to reduce wage differentials between in-house centers and subcontractors. On the other hand, normative mechanisms of compliance or union power may be insufficient to deter lower wage rates among subcontractors operating outside industry boundaries. Among the countries in this study, only Austria and France have set up sectoral bargaining for call centers, and the contract conditions and wage rates are far inferior to those found in established industries (Holst 2007; Caroli and Gautie 2008). In Germany, where the centralized system has unraveled to a greater extent, employers have large incentives and opportunities to evade sectoral bargaining by outsourcing work to subcontractors, who operate outside traditional industryboundaries. In addition, because labor market flexibility is limited by employment protection laws, employers are not as free to shift work between one set of operations and another or set up competitive contests to lower wages. Thus, in general, we expect that wage differences between in-house establishments and subcontractors will be greater in centralized systems than in more decentralized ones in liberal market and emerging market economies.

\section{Segmentation Strategies}

In contrast to outsourcing, employers use segmentation strategies to define separate groups of customers and to differentiate services based on the demand characteristics of each group. Segmenting the market facilitates price differentiation strategies by customers' value-added or their willingness to pay. Segmentation also allows companies to set up separate centers for each customer group and to match each group's demand characteristics to the human capital requirements of the job and the human resource practices needed to support that job (Batt 2000). This approach represents a depar- 
ture from geographic-based organizations that serve all customers in a given area and hire a work force that is broadly skilled and undifferentiated by pay (referred to as a "universal approach").

Segmentation strategies reorganize job structures and pay hierarchies according to the structure of the customer hierarchy. A typical pattern separates operations devoted to large business customers from those focused on small businesses or on the mass or general consumer markets. Large business centers, with their high value-added services, are typically kept in-house, although firms may outsource low-value-added telemarketing or transactional services for these business clients. Each type of center has different skill requirements, but unlike the example of outsourcing above, differences between jobs in formal education requirements are often large. Agents serving business customers are often required to have a college degree, unlike those working in mass market or "universal" centers. Under these circumstances, labor mobility between business centers and other types of centers is reduced. Past research has shown that large business centers in the United States hire mainly college graduates and offer a 15-20\% wage premium, after the analysis controls for human capital characteristics (Batt 2001).

In theory, this type of labor market segmentation based on formal education should operate similarly in different institutional environments. However, in more centralized IR systems, unions and works councils may seek to limit the reorganization of work based on these principles or the level of differentiation in pay when specialized units are established.

\section{Expected Findings}

To summarize our argument, we expect that differences in national industrial relations systems will lead to differences across countries in wage dispersion for call center workers. First, liberal market countries with more decentralized systems will have higher wage dispersion and union wage differentials than coordinated economies with more centralized systems. Second, among liberal market economies, we expect higher wage dispersion in the United States and lower dispersion in Ireland; while among coordinated economies, we expect somewhat higher wage dispersion in Germany. Wage dispersion in the emerging economies should be particularly large due to their highly segmented labor markets and lack of overall employment protections; we further explore variation among these countries in our analyses. Third, employer strategies of outsourcing and segmentation should partially explain wage variation within countries. Fourth, in-house differentials should be larger in coordinated economies than in liberal or emerging market economies, while business center differentials should be smaller.

\section{Methods}

The details of the research methodology are provided in the introduction to this special issue. It discusses the sampling strategy, survey construction and administration, variable definitions and scales, creation of the international data set, and means and standard deviations of the variables (by country). The study draws on the global call center survey, an establishment-level survey that reduces heterogeneity by focusing on one occupational group in customer services. It was administered to the general manager of each establishment and covered a series of questions regarding market conditions, collective bargaining coverage, employer strategies, organizational features, human capital characteristics, and wages. The survey applied to the "core" occupational groupthat is, the largest group of employees serving as call center agents. We provide a brief summary below and focus on specific issues that apply to this paper.

\section{Sample and Survey Administration}

The sample for this article consists of 1,819 observations from 15 of the 17 countries in the study. The Netherlands and Spain were excluded due to missing observations for key variables. Every effort was made to take a consistent approach to sampling and survey administration, but there was some varia- 
tion across countries. In each country, the sample was chosen from the largest available list of call centers (typically the membership list of the national call center employers' association), supplemented by other available sources. Because the population of call centers in most countries is small, the samples typically represent a large proportion of the entire population (with the exception of the United States).

The number of call centers by sector and the number by in-house/outsourced status in our data appear to be consistent with estimates by other call center surveys. However, sampling strategies led to an over-sampling of outsourced centers in Germany and an over-representation of the telecommunications industry in the United States. We take both of these variables into account in our data analyses below.

While most country surveys were random or stratified random samples, the teams in emerging market economies did face-toface interviews, because mail and telephone surveys yield particularly low response rates. As a result, the survey teams focused on a limited number of geographic areas (for example, Seoul in South Korea, and two call center cities in South Africa). The teams identified the largest list of call centers they could find (based on employer association lists and telephone books), and administered the surveys wherever they could get access to establishments. Thus, the samples are large and non-random.

The overall response rate for the countries in this paper was $57 \%$ (unweighted), and $68 \%$ (weighted). All countries had a response rate of at least $40 \%$, except for Ireland (23\%). In general, using employers' association lists to identify the population of centers biases the sample toward the better-operated ones, because association members tend to be more established operators, often part of large or multinational corporations.

\section{Measures}

For wage levels, we asked, "What are the gross annual earnings of the typical fulltime core employee? (By 'typical' we mean that about half the core employees are paid more and about half are paid less)." We defined gross annual earnings as total earnings before deductions and taxes, including wages, bonuses, commissions, profit sharing, and overtime pay, but excluding benefits such as pensions and health, and deferred compensation such as stock options. We converted other currencies to U.S. dollars and used the natural log transformation. We used the measure of gross annual earnings because there is great variation in the use of performance-based pay or bonuses, and we wanted to capture all earnings regardless of pay mix. We asked about the median worker because we wanted to capture the wages of the typical worker, without the influence of particularly high- or low-paid workers in a given establishment. Since there are virtually no centers in which the median worker is part-time, this definition allows us to compare full-time workers across countries. The disadvantage is that it does not allow us to take into consideration wage variation due to variation in hours worked or the greater use of part-time and contingent workers in some countries than in others. Thus, our measure is a conservative one.

The union coverage variable is an indicator of whether call center agents are covered by a collective bargaining contract. Ownership status is a dummy variable that equals 1 for in-house centers and 0 for subcontractors. For customer segment, we divided the data into centers that primarily serve large business and centers that serve all others, based on past research showing that large business is the most important differentiator (Batt 2001).

We used several measures to capture human capital and demographic characteristics. Three dummy variables measure years of education "of the typical or median worker": schooling up to age 16 (omitted category), schooling up to age 18 , and university degree. We added a measure of job complexity to provide some indication of non-observable human capital requirements of the job. Our job complexity measure is the number of weeks it takes for the typical employee to become proficient in the job. We measured tasks by whether calls are in-bound (usually involving service or service and sales) or outbound (typically telemarketing types of 
sales calls). We include the percentage of the work force that is female. We also control for organizational characteristics: size (natural $\log$ of total employment); percent of the work force that is female; age of the establishment (logged); and primary sector served (financial services, telecommunications, and all others, the omitted category).

\section{Data Analytic Strategy}

Our data analysis is in two stages. First, we did a series of calculations of overall wage dispersion for each country, using several indices, including the coefficient of variation, the standard deviation of logs, and the gini coefficient. These statistics are based on our establishment-level data, weighted by establishment size, and are presented in Table 3. Second, to examine the relative importance of collective bargaining and employer strategies of segmentation and outsourcing, we did a series of multiple regressions using the pooled international data set and robust standard errors, which provide a Huber correction for country effect that takes into account the non-independence of observations within each country. Our series of models includes the key independent variables and different sets of control variables (Table 4). We then estimated full models that include all of the control variables plus interaction terms. Because of the large number of countries, we used separate equations to examine the country interaction terms for our three independent variables (Table 5). Finally, we calculated the magnitude of the wage differential associated with each of our independent variables and whether it was statistically significant. We then compared the magnitude and significance levels of these differentials across our three types of economies, and across countries within each category (Table 6).

\section{Results}

The means, standard deviations, and pairwise correlations for the data used in this paper are provided in Table 2. The means and standard deviations, by country, are provided in Appendix $\mathbf{E}$ of the introduction.

\section{Wage Dispersion}

The analyses in Table 3 show that among the liberal market economies, the United States had the lowest bargaining coverage and the highest levels of wage dispersion (at least twice the size of Denmark's). Canada, Ireland, and Israel also had high dispersion, but somewhat lower than the United States. The United Kingdom had the lowest levels of dispersion, intermediate between the liberal and coordinated economies. Among the emerging market economies, all had high or very high levels of dispersion, with Brazil having the highest levels of any country in the study.

Among the coordinated economies, Austria, Denmark, France, and Sweden had relatively high bargaining coverage among call center workers (over 60\%), compared to Germany (34\%). Union coverage among subcontractors was also high in Austria, France, and Sweden, but not Denmark. Because the German survey over-sampled subcontractor centers, these figures may understate bargaining coverage; however, the differences between coverage for in-house centers and subcontractors in our data are not statistically significant. Denmark, France, and Sweden scored the lowest on wage dispersion measures, while Germany scored high and Austria scored very high.

These findings only partially support our predictions. As predicted, wage dispersion was higher in most of the liberal and emerging market economies than in the coordinated economies; and it was very high in the United States and most emerging market countries. However, Ireland had higher wage dispersion than expected, and the United Kingdom had lower dispersion. Similarly, while we predicted that Germany would diverge from the coordinated group, it had much higher levels of wage dispersion than we expected; and Austrian figures resemble those of the United States.

\section{Differentials Based on Union Coverage and Employer Strategies}

We now turn to our analyses that examine the relative importance of bargaining coverage and employer strategies of outsourcing 


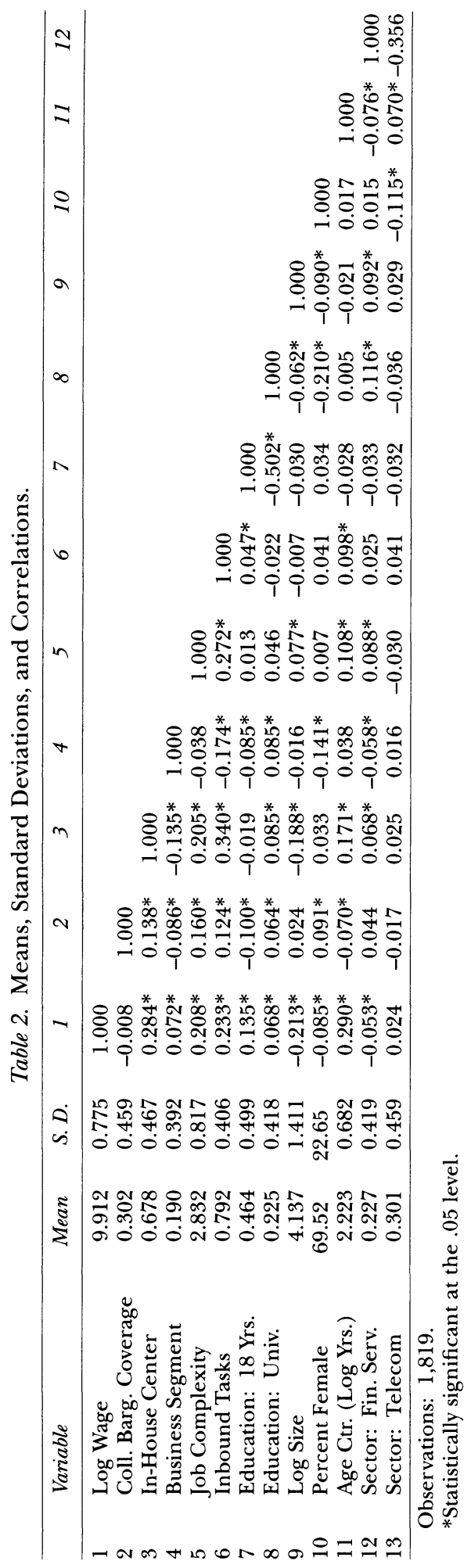




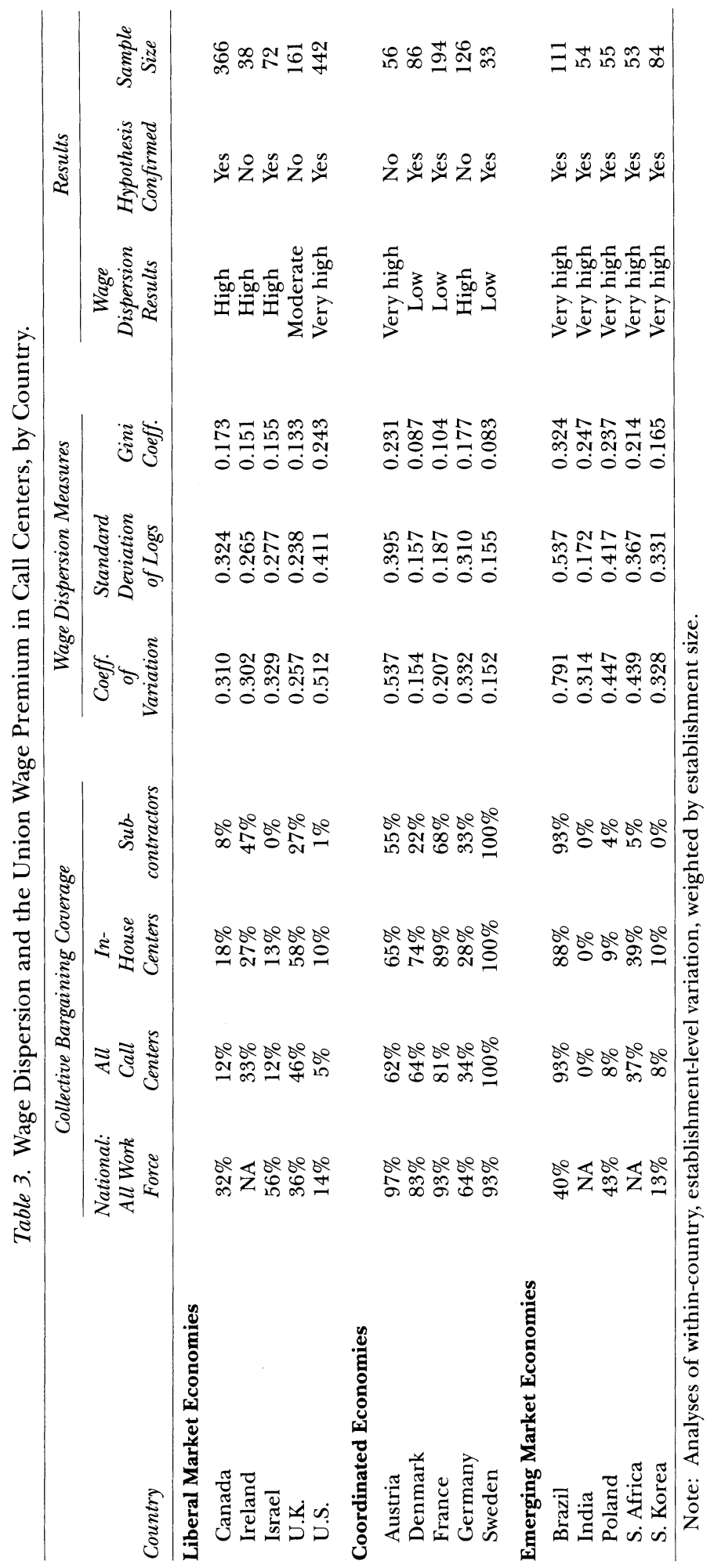


Table 4. Log Annual Earnings (Robust SE).

\begin{tabular}{|c|c|c|c|c|c|c|}
\hline \multirow[b]{2}{*}{ Variable } & \multicolumn{2}{|c|}{ Model 1} & \multicolumn{2}{|c|}{ Model 2} & \multicolumn{2}{|c|}{ Model 3} \\
\hline & Coeff. & $S E$ & Coeff. & $S E$ & Coeff. & $S E$ \\
\hline \multicolumn{7}{|l|}{ Institutions and Strategies } \\
\hline $\begin{array}{l}\text { CB Coverage } \\
\text { In-House Center } \\
\text { Business Center }\end{array}$ & $\begin{array}{l}0.080 \\
0.206 \\
0.142\end{array}$ & $\begin{array}{l}0.057 \\
0.035^{* * *} \\
0.093\end{array}$ & $\begin{array}{l}0.069 \\
0.148 \\
0.123\end{array}$ & $\begin{array}{l}0.057 \\
0.033^{* * *} \\
0.068\end{array}$ & $\begin{array}{l}0.088 \\
0.123 \\
0.102\end{array}$ & $\begin{array}{l}0.054 \\
0.024^{* * *} \\
0.059\end{array}$ \\
\hline \multicolumn{7}{|c|}{ Human Capital Characteristics } \\
\hline $\begin{array}{l}\text { Job Complexity } \\
\text { Inbound Tasks } \\
\text { Education: } 18 \text { Years } \\
\text { Education: University }\end{array}$ & & & $\begin{array}{l}0.071 \\
0.049 \\
0.149 \\
0.326\end{array}$ & $\begin{array}{l}0.012^{* * *} \\
0.050 \\
0.054^{*} \\
0.091 * * *\end{array}$ & $\begin{array}{l}0.073 \\
0.050 \\
0.126 \\
0.272\end{array}$ & $\begin{array}{l}0.013 * * * \\
0.049 \\
0.044 * \\
0.066^{* * *}\end{array}$ \\
\hline \multicolumn{7}{|c|}{ Organizational Characteristics } \\
\hline $\begin{array}{l}\text { Size } \\
\text { Percent Female } \\
\text { Age of Center } \\
\text { Sector: Fin. Serv. } \\
\text { Sector: Telecom }\end{array}$ & & & & & $\begin{array}{r}-0.042 \\
-0.003 \\
0.050 \\
0.016 \\
0.033\end{array}$ & $\begin{array}{l}0.010^{* * *} \\
0.001^{* * *} \\
0.013^{* * *} \\
0.019 \\
0.025\end{array}$ \\
\hline \multicolumn{7}{|l|}{ Countries } \\
\hline $\begin{array}{l}\text { Liberal Market } \\
\text { Canada } \\
\text { Ireland } \\
\text { Israel } \\
\text { U.K. }\end{array}$ & $\begin{array}{r}0.027 \\
-0.059 \\
-1.211 \\
-0.129\end{array}$ & $\begin{array}{l}0.014 \\
0.015^{* * *} \\
0.012^{* * *} \\
0.022^{* * *}\end{array}$ & $\begin{array}{l}-0.039 \\
-0.127 \\
-1.147 \\
-0.170\end{array}$ & $\begin{array}{l}0.015^{*} \\
0.021 * * * \\
0.014^{* * *} \\
0.025^{* * *}\end{array}$ & $\begin{array}{r}0.000 \\
-0.119 \\
-1.120 \\
-0.132\end{array}$ & $\begin{array}{l}0.016 \\
0.017^{* * *} \\
0.021^{* * *} \\
0.025^{* * *}\end{array}$ \\
\hline $\begin{array}{l}\text { Coordinated } \\
\text { Austria } \\
\text { Denmark } \\
\text { France } \\
\text { Germany } \\
\text { Sweden }\end{array}$ & $\begin{array}{r}-0.539 \\
0.313 \\
-0.364 \\
-0.233 \\
-0.078\end{array}$ & $\begin{array}{l}0.032^{* * *} \\
0.023^{* * *} \\
0.037^{* * *} \\
0.024^{* * *} \\
0.051\end{array}$ & $\begin{array}{r}-0.412 \\
0.301 \\
-0.496 \\
-0.132 \\
-0.124\end{array}$ & $\begin{array}{l}0.047^{* * *} \\
0.019^{* * *} \\
0.056^{* * *} \\
0.042^{* *} \\
0.050^{*}\end{array}$ & $\begin{array}{r}-0.385 \\
0.304 \\
-0.469 \\
-0.121 \\
-0.127\end{array}$ & $\begin{array}{l}0.040^{* * * *} \\
0.019^{* * *} \\
0.044^{* * *} \\
0.034^{* * *} \\
0.039^{* *}\end{array}$ \\
\hline $\begin{array}{l}\text { Emerging Market } \\
\quad \text { Brazil } \\
\text { India } \\
\text { Poland } \\
\text { S. Africa } \\
\text { S. Korea }\end{array}$ & $\begin{array}{l}-2.038 \\
-2.408 \\
-1.441 \\
-0.977 \\
-0.788\end{array}$ & $\begin{array}{l}0.044^{* * *} \\
0.023^{* * *} \\
0.016^{* * *} \\
0.009^{* * *} \\
0.024^{* * *}\end{array}$ & $\begin{array}{l}-1.959 \\
-2.554 \\
-1.487 \\
-0.858 \\
-0.818\end{array}$ & $\begin{array}{l}0.054^{* * *} \\
0.042^{* * *} \\
0.019^{* * *} \\
0.033^{* * *} \\
0.020^{* * *}\end{array}$ & $\begin{array}{l}-1.885 \\
-2.499 \\
-1.485 \\
-0.888 \\
-0.695\end{array}$ & $\begin{array}{l}0.058^{* * *} \\
0.055^{* * *} \\
0.021^{* * *} \\
0.026^{* * *} \\
0.034^{* * *}\end{array}$ \\
\hline Constant & 10.117 & $0.040 * * *$ & 9.801 & $0.073 * * *$ & 10.053 & $0.087 * * *$ \\
\hline $\begin{array}{l}\text { Sample } \\
\text { R-Squared }\end{array}$ & \multicolumn{2}{|c|}{$\begin{array}{l}1,819 \\
0.818\end{array}$} & \multicolumn{2}{|c|}{$\begin{array}{l}1,819 \\
0.840\end{array}$} & \multicolumn{2}{|c|}{$\begin{array}{l}1,819 \\
0.851\end{array}$} \\
\hline
\end{tabular}

*Statistically significant at the .05 level; **at the .01 level; ***at the .001 level.

and segmentation. Table 4 shows the results from regression models that control for country effects as well as human capital and organizational variables. Table 5 includes the country interaction terms, and Table 6 provides the calculations of wage differentials based on these regression analyses. Results in Table 4 show that, for the dataset as a whole, the distinction between in-house centers and subcontractors is statistically significant in all of the equations, but the influence of unions and segmentation strategies is not. Several of the human capital and organizational control variables are statistically significant in the expected direction. Their addition does not change the significance level, but lowers the size of the coefficient on in-house centers from $21 \%$ in the model with country controls to $12 \%$ in the full model.

Results relevant to country-level differ- 
Table 5. Log Wage Regressions with Interaction Terms (Robust SE).

\begin{tabular}{|c|c|c|c|c|c|c|}
\hline \multirow[b]{2}{*}{ Variable } & \multicolumn{2}{|c|}{ Model 1} & \multicolumn{2}{|c|}{ Model 2} & \multicolumn{2}{|c|}{ Model 3} \\
\hline & Coeff. & $S E$ & Coeff. & $S E$ & Coeff. & $S E$ \\
\hline \multicolumn{7}{|c|}{ Institutions and Strategies } \\
\hline CB Coverage & -0.015 & 0.029 & 0.096 & 0.050 & 0.085 & 0.051 \\
\hline In-House Center & 0.115 & $0.020^{* * *}$ & 0.233 & $0.024 * * *$ & 0.122 & $0.023^{* * *}$ \\
\hline Business Center & 0.105 & 0.058 & 0.108 & 0.057 & 0.036 & $0.015^{*}$ \\
\hline Country Interactions & \multicolumn{2}{|c|}{ Union Interactions } & \multicolumn{2}{|c|}{ In-House Interactions } & \multicolumn{2}{|c|}{ Segment Interactions } \\
\hline \multicolumn{7}{|l|}{ Liberal Market } \\
\hline Canada & 0.246 & $0.041^{* * *}$ & -0.102 & $0.020 * * *$ & 0.006 & 0.013 \\
\hline Ireland & 0.284 & $0.062 * * *$ & & & 0.215 & $0.022 * * *$ \\
\hline Israel & 0.034 & 0.030 & -0.230 & $0.029 * * *$ & -0.065 & $0.011^{* * *}$ \\
\hline U.K. & 0.022 & 0.034 & -0.206 & $0.017 * * *$ & 0.052 & $0.015^{* * *}$ \\
\hline U.S. & 0.229 & $0.041 * * *$ & -0.150 & $0.036^{* * *}$ & 0.295 & $0.014 * * *$ \\
\hline \multicolumn{7}{|l|}{ Coordinated } \\
\hline Austria & -0.005 & 0.043 & -0.034 & 0.020 & 0.028 & 0.015 \\
\hline Denmark & 0.093 & $0.042 *$ & -0.155 & $0.023 * * *$ & 0.035 & 0.025 \\
\hline France & 0.020 & 0.024 & -0.167 & $0.021^{* * *}$ & 0.020 & 0.010 \\
\hline Germany & 0.313 & $0.051 * * *$ & 0.029 & 0.020 & -0.130 & $0.014^{* * *}$ \\
\hline Sweden & & & -0.040 & 0.043 & (DR) & \\
\hline \multicolumn{7}{|l|}{ Emerging Market } \\
\hline Brazil & -0.257 & $0.037 * * *$ & 0.124 & $0.052 *$ & -0.141 & $0.026^{* * *}$ \\
\hline India & & & -0.164 & $0.024 * * *$ & -0.031 & $0.009 * * *$ \\
\hline Poland & & & -0.261 & $0.026^{* * *}$ & -0.046 & $0.021^{*}$ \\
\hline S. Africa & 0.029 & 0.022 & -0.202 & $0.016^{* * *}$ & -0.175 & $0.020 * * *$ \\
\hline S. Korea & 0.297 & $0.033^{* * *}$ & -0.169 & $0.016^{* * *}$ & -0.015 & 0.037 \\
\hline HC Controls & Yes & & Yes & & Yes & \\
\hline Organization Ctrls. & Yes & & Yes & & Yes & \\
\hline Country Controls & Yes & & Yes & & Yes & \\
\hline Constant & 10.058 & $0.088^{* * *}$ & 10.077 & $0.089 * * *$ & 9.982 & $0.092 * * *$ \\
\hline Sample & 1,819 & & 1,819 & & 1,819 & \\
\hline R Squared & 0.857 & & 0.854 & & 0.857 & \\
\hline Root MSE & 0.297 & & 0.300 & & 0.296 & \\
\hline
\end{tabular}

*Statistically significant at the .05 level; **at the .01 level; ***at the .001 level.

ences are shown in Table 5. The models replicate the full model in Table 4 , but add countryinteraction terms. Model 1 includes interaction terms for the union effect, model 2 for the in-house effect, and model 3 for the segmentation effect. Again, in Table 5, only the coefficient on in-house centers remains statistically significant and large in all of the models. Most of the human capital, organizational controls, and country interaction terms are also statistically significant. The omitted category is the United States. In analyses not shown, we included additional controls-for example, tenure of the work force, whether the establishment was part of a larger orga- nization, and whether the center primarily served an international market-but these did not change the results and reduced our sample sizes in several countries, so we did not include them in the final analyses.

Our main hypotheses considered the effect of three factors on wage differentials: collective bargaining (CB) coverage, in-house versus subcontractor status, and centers serving business customers versus other customers. We also hypothesized that union wage differentials and business center differentials would be smaller in coordinated economies than in liberal or emerging market economies, while in-house differentials would be larger. 
Table 6. Within-Country Wage Differentials: Collective Bargaining Coverage and Business Strategies.

\begin{tabular}{lccc}
\hline Country & $\begin{array}{c}\text { Union } \\
\text { Differential }\end{array}$ & $\begin{array}{c}\text { In-House } \\
\text { Differential }\end{array}$ & $\begin{array}{c}\text { Business } \\
\text { Differential }\end{array}$ \\
\hline LME & $0.156^{*}$ & $0.098^{* * *}$ & $0.185^{* *}$ \\
Canada & $0.231^{* * *}$ & $0.132^{* * *}$ & $0.042^{* * *}$ \\
Ireland & $0.268^{* * *}$ & $0.233^{* * *}$ & $0.250^{* * *}$ \\
Israel & 0.019 & 0.003 & $-0.030^{* *}$ \\
U.K. & 0.007 & 0.027 & $0.088^{* * *}$ \\
U.S. & $0.215^{* * *}$ & $0.083^{* * *}$ & $0.331^{* * *}$ \\
CME & 0.081 & $0.146^{* *}$ & 0.004 \\
Austria & -0.020 & $0.199^{* * *}$ & $0.063^{* *}$ \\
Denmark & $0.078^{* * *}$ & $0.078^{*}$ & $0.070^{*}$ \\
France & 0.005 & $0.066^{*}$ & $0.055^{* *}$ \\
Germany & $0.297^{* * *}$ & $0.262^{* * *}$ & $-0.095^{* * *}$ \\
Sweden & & $0.193^{* * *}$ & $0.036^{*}$ \\
EME & -0.118 & 0.157 & $-0.074^{*}$ \\
Brazil & $-0.272^{* * *}$ & $0.358^{* * *}$ & $-0.106^{* * *}$ \\
India & & $0.069^{* * *}$ & 0.005 \\
Poland & -0.015 & -0.028 & -0.011 \\
S. Africa & 0.014 & $0.031^{*}$ & $-0.139^{* * *}$ \\
S. Korea & $0.282^{* * *}$ & $0.064^{* * *}$ & 0.020 \\
\hline
\end{tabular}

*Statistically significant at the .05 level; **at the .01 level; ***at the .001 level.

To test these hypotheses, we calculated the country-specific wage differentials (for union, in-house, and business segment status) by adding the coefficients on the main independent variable (for example, union) and the country interaction term (for example, Austria*union) from Table 5. This yields the (union) wage differential for each country. We also ran a series of regressions (not shown) with dummy variables for the union and non-union category in each country (with U.S. non-union as the omitted category). Subtracting the non-union category from the union category produces the same results. (We report the analyses with interaction terms because they take up considerably less space.) Finally, we tested whether the union and non-union dummies for each country were statistically significantly different. We did the same analysis for in-house center and the business segment dummies. We also did this set of analyses for the categories of coordinated, liberal, and emerging market economies; the results are presented in Table 6.
The results show that the union wage differential was large $(15.6 \%)$ and statistically significant for liberal market economiesparticularly Canada, Ireland, and the United States-but insignificant for coordinated economies. These results are consistent with predictions based on past research. For emerging markets as a group, there was no consistent union wage effect. More important, variation among the countries in each of these categories is noteworthy. Among liberal market countries, the United Kingdom and Israel had no statistically significant union premium, and thus resemble the coordinated economies more than the liberal ones. By contrast, Germany diverged substantially from the coordinated pattern, with an estimated differential of $29.7 \%$-higher than in most of the liberal market economies. Denmark also had a statistically significant, but much smaller, union differential (7.8\%). Among emerging market economies, the cross-national patterns were widely different, with a statistically significant negative differential in Brazil and a positive one in Korea. We explored various models with alternative controls, but the negative union coefficient in Brazil remained robust in almost all estimations. We believe it is related to unions being concentrated in centers and sectors that were lower-paying to begin with. In addition, Brazilian call centers included a large number of multinational centers, owned by Spanish telecommunications companies among others, and these paid higher wages than Brazilian-owned centers serving the domestic market, but were rarely unionized.

The wage premium for in-house centers compared to subcontractors, by contrast, was positive and statistically significant in all but three countries in the study. Moreover, it is noteworthy that all of the coordinated market countries had at least some wage premium for in-house centers, and several had larger in-house differentials than did liberal or emerging market countries. For example, Austria, Sweden, and Germany had particularly large differentials (19-26\%) compared to Israel and the United Kingdom (non-significant), the United States $(8.3 \%)$, and India, Poland, South Africa, or South Korea (ranging from insignificant to $7 \%$ ). 
This is suggestive that there may be more incentives in coordinated economies than in others to use subcontracting to lower wages and a more structured institutional divide between in-house centers and subcontractors.

Significant wage premia for centers serving business clients were also widespread, but there was no consistent difference between countries in the three groups of economies. The United States and Ireland stand out as having quite large wage differentials, on average $33 \%$ and $25 \%$, respectively; but most of the other countries had small differentials, in the range of 3-9\%. In addition, in four of the countries in the study-Germany, Israel, Brazil, and South Africa-business centers paid significantly less than other centers (ranging from 3\% in Israel to $10-14 \%$ in the other three countries). We know from field research that some business-to-business centers are set up exclusively to handle the most transactional work for these clients, and this would explain why some business-to-business centers in our study had low wages; however, we do not have an institutional explanation for why we find this pattern in some countries versus others-particularly as these countries differ so dramatically in their institutional arrangements.

These findings regarding union coverage and employer strategies are statistically significant after we control for a range of human capital and organizational characteristics of the establishments in the study. Most of the human capital and organizational controls are statistically significant in the expected direction and do explain some of the variance in wages, except for the emerging market countries.

In general, these results show that there was considerable wage flexibility at the establishment level across most of the countries in the study, including the coordinated economies. They also show that the general categories of liberal, coordinated, and emerging market systems are of only limited value for explaining patterns of wage variation in this sector. Rather, we find a small number of countries with relatively small wage dispersion and institutional resilience (Denmark, France, and Sweden) among a much larger number that showed considerable wage dispersion and wage differentials based on union coverage and business strategies of outsourcing and segmentation. The statistically significant difference in wages between in-house centers and subcontractors is perhaps the most consistent finding in the study, although the range of variation in the magnitude of the differential across countries is large.

\section{Discussion and Conclusions}

In this study, we examined the interplay between existing industrial relations systems and the emergence of a new set of economic activities. We focused on the growth of call centers because they represent a serious challenge to existing collective bargaining institutions: they are highly mobile operations and are ideally suited to escape from existing institutional rules based on traditionally defined sectors. Many operate in a limbo between historically defined industry boundaries, and unions in most countries have found it difficult to organize or represent workers in these new organizations.

Our findings may be summarized as follows. First, in the coordinated economies that continue to have relatively centralized bargaining systems-primarily Denmark, France, and Sweden-we found that collective bargaining coverage was high, and wage dispersion in call centers followed past patterns and was relatively low. These countries also had small or statistically insignificant union wage differentials. This group shows the most institutional resilience in the face of this new set of economic activities. Austria and Germany, by contrast, resemble the liberal and emerging market countries in their level of overall wage dispersion; and Germany (but not Austria) had a large union wage premium rivaling that in the United States. These differences between Denmark, France, and Sweden on the one hand, and Austria and Germany on the other, are consistent with recent research on wage patterns in these countries (Westergard-Nielsen 2008; Caroli and Gautie 2008; Holst 2008; Bosch and Weinkopf 2008).

Second, consistent with past research, wage dispersion in liberal market economies was high, with the highest levels in the United 
States and Canada. However, Ireland's dispersion was higher than expected, while the United Kingdom's level was intermediate between the liberal and coordinated market groups. The United Kingdom and Israel also had no statistically significant union wage premium in this sector. The U.K. findings are consistent with recent studies based on national wage data (for example, Card et al. 2003; Bryson 2002). The U.K. pattern may be explained by the relatively weak bargaining power of unions, as well as the possibility that U.K. unions have focused on strengthening training and raising the wages at the bottom via the introduction and enhancement of the National Minimum Wage law. The Israeli pattern may be explained by the continued influence of some corporatist traditions, despite the extensive deregulation of labor markets that has occurred in that country.

Third, all of the emerging market countries had high or very high wage dispersion in this sector, as expected. Beyond that, however, the results are nationally specific and difficult to interpret. As stated earlier, our goal in this paper was to explore how wage patterns in the emerging market countries compared to those in advanced economies, as the sector has become increasingly international; but past research provides insufficient guidance for specific predictions. Our results point to the need for more country-specific research and development of theory for each of these countries. For example, while some research suggests that South Korea has moved toward a more coordinated system, the high levels of dispersion and high union wage premium suggest that this is not the case, at least for this sector. Specific features of this sector in emerging markets also are undoubtedly important, including the effects of off-shoring brought by multinationals combined with the importance of the informal sector, which may create a unique path of industrial development for this sector in each country.

Fourth, an important source of wage variation in almost all countries in this study was employers' choice of subcontracting strategy. Surprisingly, even among coordinatedeconomy countries with relatively centralized bargaining, significant differences in wage levels existed based on whether the center remained in the primary firm or was owned and operated by subcontractors. The growth of subcontracting has been an important phenomenon across many industries in recent decades. The findings in this study suggest that there is a convergence in employer strategies of subcontracting across countries, which is producing a consistent source of wage differentiation within each country. This pattern is consistent with recent arguments that employer practices are converging across countries, which produces divergent wage outcomes within countries (Katz and Darbishire 2000). The findings signal that subcontracting is an important new source of labor market segmentation in this sector.

There are important limitations to this study that are discussed more fully in the introduction to this volume. The central methodological challenge was defining the population of call centers and obtaining a nationally representative sample of establishments. For this paper on wage determination, we believe that there is an upward bias in wage levels in our sample because it principally drew from employers' association lists, in which large corporations with more sophisticated HR practices tend to be overrepresented. If so, then our data on wages should be truncated at the lower end, biasing wage level estimates up and dispersion estimates down.

The dataset is based on the survey responses of one person in each center, which potentially introduces more error into the data than if multiple respondents had been surveyed. This also creates problems of single-source bias. This problem may be minimized both because the worksites were generally small (the median size was 50 core employees) and because research has found that single-respondent bias is lower for establishment-level surveys than for surveys of larger organizational units (Gerhart et al. 2000). The survey also sought answers to objective questions (for example, whether collective bargaining was present or absent), rather than subjective opinions.

Furthermore, we are aware of the difficulties inherent in all international comparative research. A standardized questionnaire re- 
duces the ability to capture national diversity, differences in meaning for the same variable cross-nationally, and norms that are specific to one country but are unobserved. In addition, the cross-sectional analysis in this case limits our ability to make causal inferences. We can only demonstrate whether these relationships varied across countries and whether the findings are consistent with existing theories. We think there is reasonable evidence that variation in wages was influenced by the role of unions and the actions of business actors in this sector.

We also are aware of the fact that at the time of this study, this new sector was at different stages of development among these countries. The management models at call centers might have been relatively mature in the United States and United Kingdom, and more experimental in the EU continental countries, where the sector was newer. Similarly, in emerging markets, the sector expanded dramatically after 2000 , influenced by multinational off-shoring and new entrants to the field. Thus, the future of its institutional evolution remains uncertain, and there is need for longitudinal research on this question.

More generally, this study identifies widespread patterns of wage flexibility at the establishment level based on union coverage and employer strategies, even among some coordinated economies with traditional patterns of low wage dispersion. We find patterns of institutional divergence and resilience among a small number of coordinated economies amidst a wider pattern of convergence toward more liberal or flexible labor market regimes. These findings are specific to the emerging call center sector, but may also apply to other IT-based occupations with similar characteristics. However, while we have identified general patterns of wage flexibility in this sector, understanding formal national institutions and coordination mechanisms is only a first step. This approach must be combined with more fine-grained institutional analysis (Maurice, Sellier, and Silvestre 1986; Sorge 2005) to grasp the real meaning of the interplay between collective representation, institutional rules, and employer strategies in these new sector activities.

\section{REFERENCES}

Batt, Rosemary. 2000. "Strategic Segmentation and Frontline Services: Matching Customers, Employees, and Human Resource Systems." International Journal of Human Resource Management, Vol. 11, No. 3, pp. 540-61. 2001. "Explaining Intra-Occupational Wage Inequality in Telecommunications Services: Customer Segmentation, Human Resource Practices, and Union Decline." Industrial and Labor Relations Review, Vol. 54, No. 2A, pp. 425-49.

Behrens, Martin, and Franz Traxler. 2003. "Collective Bargaining Coverage and Extension Procedures." EIR Observer, February, S. i-viii.

Blanchflower, David. 2006. "A Cross-Country Study of Union Membership." IZA DP Discussion Paper Series, March.

Blanchflower, David, and Alex Bryson. 2002. "Changes over Time in Union Relative Wage Effects in the UK and the US Revisited." NBER Working Paper No. 9395, December.

Blau, Francine, and Lawrence Kahn. 1999. "Institutions and Laws in the Labor Market." In Orley Ashenfelter and David Card, eds., Handbook of Labor Economics, Vol. 3, Chap. 25. Amsterdam: Elsevier.
Bosch, Gerhard, and Claudia Weinkopf, eds. 2008. Low Wage Work in Germany. New York: Russell Sage Foundation.

Brown, William, Paul Marginson, and Janet Walsh. 2003. "The Management of Pay as the Influence of Collective Bargaining Diminishes.” In Paul Edwards, ed., Industrial Relations: Theory and Practice in Britain, 2nd ed., pp 189-213. Oxford, England: Blackwell.

Bryson, Alex. 2002. "The Union Membership Wage Premium: An Analysis Using Propensity Score Matching." Centre for Economic Performance paper, London School of Economics, January.

Calmfors, Lars, and John Driffil. 2002. "Centralization of Wage Bargaining." In Alison Booth, ed., TheEconomics of Labor Unions, Vol. 2, pp. 353-97. International Library of Critical Writings in Economics, Vol. 147. Cheltenham, U.K., and Northampton, Mass.: Elgar.

Card, David, and Richard Freeman, eds. 1993. Small Differences That Matter: Labor Markets and Income Maintenance in Canada and the United States. Chicago: University of Chicago Press.

Card, David, Thomas Lemieux, and W. Craig Riddell. 2004. "Unionization and Wage Inequality." Journal 
of Labor Research, Vol. 25, No. 4 (Fall), pp. 519-62.

Carley, Mark. 2006. "Key Themes in Global Industrial Relations: Minimum Wages and Relocation of Production." European Foundation for the Improvement of Living and Working Conditions. Luxembourg: Office of Official Publications of the European Union.

Caroli, Eve, and Jerome Gautie, eds. 2008. Low Wage Work in France. New York: Russell Sage Foundation.

Cohen, Yinon, Yitzhak Haberfeld, Guy Mundlak, and Ishak Saporta. 2003. "Unpacking Union Density: Membership and Coverage in the Transformation of the Israeli IR System." Industrial Relations, Vol. 42, No. 4, pp. 692-711.

Donnelly, Eddy, and Stephen Dunn. 2006. "Ten Years After: South African Employment Relations Since the Negotiated Revolution." British Journal of Industrial Relations, Vol. 44, No. 1, pp. 1-29.

Gerhart, Barry, Patrick Wright, Gary McMahan, and Scott Snell. 2000. "Measurement Error in Research on the Human Resources and Firm Performance Relationship: How Much Error Is There and How Does It Influence Effect Size Estimates?” Personnel Psychology, Vol. 53, No. 4, pp. 803-34.

Gonzaga, Gustavo. 2003. "Labor Turnover and Labor Legislation in Brazil.” Economia (Fall), pp. 165-222.

Hall, Peter, and David Soskice. 2001. Varieties of Capitalism: The Institutional Foundations of Comparative Advantage. Oxford: Oxford University Press.

Holman, David, Rosemary Batt, and Ursula Holtgrewe. 2007. "The Global Call Center Report: International Perspectives on Management and Employment." URL: www.globalcallcenter.org.

Holst, Hoja. 2008. "The Political Economy of Trade Union Strategies in Austria and Germany: The Case of Call Centres." European Journal of Industrial Relations, Vol. 14, No. 1, pp. 25-45.

Katz, Harry, and Owen Darbishire. 2000. Converging Divergences: Worldwide Changes in Employment Systems. Ithaca, N.Y.: ILR Press (an imprint of Cornell University Press).

Kim, Dong-One, and Seongsu Kim. 2003. "Globalization, Financial Crisis, and Industrial Relations: The Case of South Korea." Industrial Relations, Vol. 42, No. 3, pp. 341-67.

Republic of South Africa, Department of Labour. 2005. Labour Market Review 2005. www.labour.gov.za.

Lee, Won-Duck, and Byoung Hoon Lee. 2003. "Will the Model of Uncoordinated Decentralization Persist? Change in Korean Industrial Relations after the Financial Crisis." In Harry C. Katz, Won-Duck Lee, and Joohee Lee, The New Structure of Labor Relations. Ithaca, N.Y.: ILR Press (an imprint of Cornell University Press). Low Pay Commission, Great Britain. 2005. "National Minimum Wage: Low Pay Commission Report 2005." Marginson, Paul, James Arrowsmith, and Keith Sisson. 2003. "Between Decentralization and Europeanization: Sectoral Bargaining in Four Countries and Two Sectors." European Journal of Industrial Relations, Vol. 9, No. 2, pp. 163-87.

Maurice, Marc, François Sellier, and Jean-Jacques Silvestre. 1986. The Social Foundations of Industrial Power. Cambridge, Mass.: MIT Press.

Mundlak, Guy. 2007. "Fading Corporatism: Israel's Labor Law and Industrial Relations Tradition." Ithaca and London: ILR Press (an imprint of Cornell University Press).

OECD. 1997. "Economic Performance and the Structure of Collective Bargaining." OECD Employment Outlook, Chap. 3, pp. 63-92. Paris.

. 2004. "Wage Setting Institutions and Outcomes." OECD Employment Outlook, Chap. 3, pp. 128-77. Paris.

Parsons, Nick. 1995. French Industrial Relations in the New World Economy. London: Routledge.

Schulten, Thorsten, Reinhard Bispinck, and Claus Schäfer. 2006. Minimum Wages in Europe. Brussels: European Trade Union Institute (ETUI-REHS).

Sellier, François. 1990. "L'évolution des règles sur les salaires dans le système français de relations professionnelles." In Jean-Daniel Reynaud, François Eyraud, Cathrine Paradeise, and Jean Saglio, eds., Les Systèmes de Relations Professionnelles. Paris: Editions du CNRS.

Sorge, Arndt. 2005. The Global and the Local: Understanding the Dialectics of Business. Oxford: Oxford University Press.

Streeck, Wolfgang. 1991. "On the Institutional Conditions of Diversified Quality Production.” In Egon Matzner and Wolfgang Streeck, eds., Beyond Keynesianism: The Socio-Economics of Production andFullEmployment, pp. 21-61. Aldershot: Edward Elgar.

U.S. Department of Labor. 2002. "Foreign Labor Trends: Brazil." Washington: U.S. DOL, Bureau of International Labor Affairs. FLT 02-04.

Westergaard-Nielsen, Niels, ed. 2008. Low Wage Work in Denmark. New York: Russell Sage Foundation. 